\title{
ALTERNATIVE SOURCES OF FUNDING FOR THE DEVELOPMENT OF UNITED TERRITORIAL COMMUNITIES
}

\author{
A. Poltorak, Doctor of Economics, Associate Professor \\ ORCID ID: 0000-0002-9752-9431 \\ 0. Melnyk, PhD (Economics), Associate Professor \\ ORCID ID: 0000-0001-8639-7755
}

I. Baryshevska, PhD (Economics), Associate Professor

ORCID ID: 0000-0003-3851-160X

Zh. Ihnatenko, Teacher of the Foreign Languages Department

ORCID ID: 0000-0003-1115-1325

Mykolayiv National Agrarian University

The article proves that it is important to strengthen financial capacity of united territorial communities through different financial and socio-economic mechanisms in the modern conditions of communities' decentralization and further development. The article analyzes the current trends in financing the development of united territorial communities, reveals the benefits and opportunities for attracting alternative sources of funding. An algorithm for attracting grant funds for the development of UTC and other proposals that will increase the financial capacity of UTC in the long term and the implementation of local development initiatives are proposed. capacity.

Key words: alternative sources of financing, united territorial communities, grant funds, projects, financial

Formulation of the problem. One of the main tasks of local governments in most countries is to organize the search for extra-budgetary sources of funding and to establish cooperation with various funds and grant programs. The important area of activity for local communities in Ukraine should be the search for alternative sources of funding and attracting grant funds to address local development needs because they have limited budgetary resources. Therefore, the study of the content and forms of promising areas of financing for the development of united territorial communities (hereandafter - UTC) is relevant today.

Analysis of recent research and publications. The theoretical and practical aspects of attracting various sources of financing for local development are studied by the Ukrainian and foreign scientists such as M. Buryak [1], N. Vasilieva, N. Hrynchuk, T. Derun, V. Kuybida [2], A. Poltorak [3], N. Spasiv [4] and others. They reveal the features of attracting financial resources for local development, identify their advantages and disadvantages, describe the modern paradigm of finance of united territorial communities and more. At the same time, today the directions of attracting alternative sources for financing UTC need a more fundamental study, taking into account current trends in socio-economic development.

Formulation of research goals. The purpose of the study is to assess the status and justification of promising areas of financing the development of UTC through alternative sources to improve their efficiency.

Presentation of the main research material. Today the main aspect of the integral system of local government is that the Constitution of Ukraine determines the right of a territorial community to independently resolve issues of local importance, and the Law of Ukraine «On Local Self-Government in Ukraine» [5] stipulates that a territorial community is the residents united by permanent residence within a village, settlement, city, that are independent administrative-territorial units, or a voluntary association of residents of several villages, have the ability to independently resolve issues of local importance through the particular local government departments.

At the same time, changes to the Budget Code have become a key impetus for territorial communities to unite because in the case of unification, they are endowed with resources and powers as in cities of regional importance. As a result 
of the process of financial decentralization there is a distribution of responsibilities, powers, functions, financial resources between the central, regional and subregional levels of government [1].

The process of unification of territorial communities began in mid-2015, at the end of which 159 UTCs were established. At the same time, their number has been growing rapidly every year and in 2019 increased more than 6 times. By September 10, 2020, 983 UTCs have been established in Ukraine.

The results of financial decentralization indicate at the annual increase in local budgets' own revenues.
Thus, during 2018, incomes of own revenues to the general fund of local budgets of Ukraine amounted to UAH 234.1 billion, which is UAH 41.4 billion or $21.5 \%$ more than in the previous year (Fig. 1). During five years of financial decentralization, local budget revenues are expected to quadruple and will be UAH 267 billion (in January-November 2019, it was UAH 250.5 billion).

The increase in own revenues was achieved mainly due to the growth of tax revenues. After all, during 2014-2019, the role of local taxes and fees in the formation of relevant budgets increased.

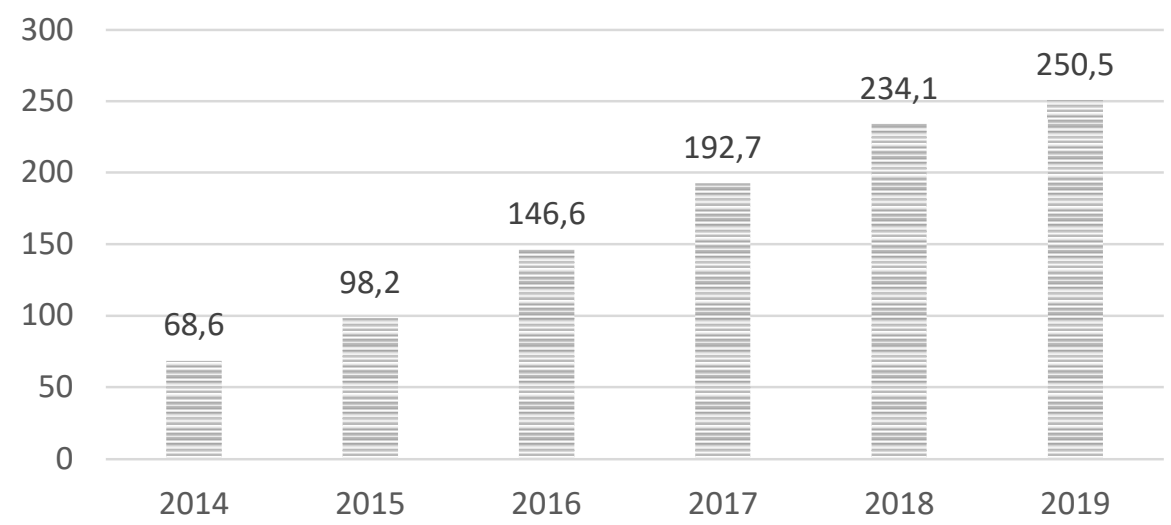

Fig. 1 - Private revenues of the general fund of local budgets, 2014-2019, UAH billion

Source: made by the authors according to [6], * 2019 (January-November)

Analysis of the implementation of own revenues of local budgets shows a steady trend of their pace growth. Thus, if in January-November 2016 own income for per inhabitant became 3385.5 UAH, for the same period in 2019 their volume almost doubled and was to 6763.6 hryvnias. At the same time, positive growth rates are typical both for the amount of personal tax income (PIT) per capita and for local taxes and fees per capita. The size of these indicators in January-November 2019 increased by $25.8 \%$ and $26.7 \%$, respectively, comparing to the same period last year (Fig. 2).

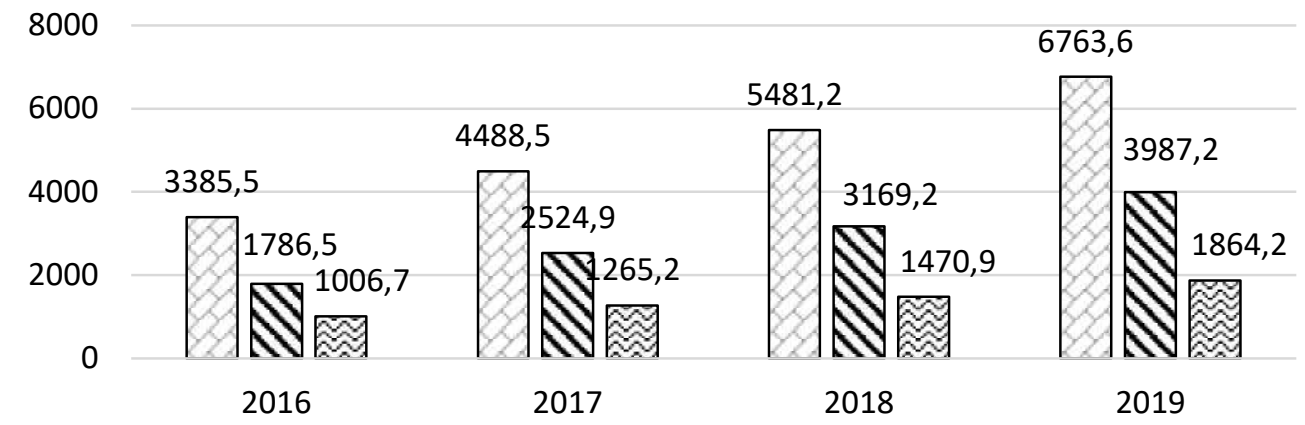

$\square$ Own income for per inhabitant $\mathbf{\nabla}$ PIT per capita $\square$ Local taxes and fees per capita

Fig. 2 - Growth of revenues of the general fund of local budgets per 1 inhabitant in January-November 2016-2019, UAH

Source: made by the authors according to data [6] 
In the period from 2014 to 2019 there is a significant increase in the state support for local communities. It should be noted that since 2017, support has been provided for the construction of sports facilities, financing of sectoral regional authorities, UTC infrastructure. The activity of the State Fund for Regional Development (hereinafter SFRD) is important in strengthening the financial base of the united territorial communities, which provides funding for regional development projects on a competitive basis and in accordance with regional development strategies and action plans for their implementation. During 2015-2019, the amount of funding from the State Fund for Rural Development has a steady upward trend, in 2019, UAH 7.7 billion was allocated for the needs of regional development. (or $28.3 \%$ more than in 2018).

Pointing at the important role of budget resources in the development of UTC, it should be noted that at the local level there is a number of unresolved issues that are too much for the community budget, but can be successfully addressed with other resources, including alternative (grant). Today they are represented by: fundraising; common cost (crowdfunding platforms); donor programs and opportunities in the context of decentralization reform (grants from the European Union, grants from the United States Agency for International Development (USAID), financial assistance from international projects, etc.).

In addition, most UTCs have a number of problems in public financial management. Thus, based on the results of the state financial audits of UTCs in various oblasts, which were completed in 2019, the problems of inefficient management of revenues and expenditures of the community budget and others were identified and systematized. In particular, the typical problems of inefficient UTC budget revenue management are:

1) the use of low land tax and rent rates;

2) the presence of arrears of land tax and rent for land;

3 ) the incomplete realization of the fiscal potential of the property tax, other than land, due to lack of access to the State Register of Real Rights;

4) the loss of PIT revenues due to two main reasons (informal employment and PIT payment at the place of registration of the parent company, and not at the place of actual location of business entities which are divisions / branches of other companies and operate in the UTC) [7 ].

In addition, a number of key aspects of inefficient management of UTC budget expenditures have been identified [7]:

1) spending of resources to pay for utilities of individual entities;

2) constant subsidization of utilities and failure to take measures to achieve at least a break-even point, which does not contribute to improve the financial condition of utilities and quality service;

3) irrational spending in connection with the nonoptimized network of educational and cultural institutions. These spending are primarily related to wages and maintenance of institutions with significant underutilization of their capacity;

4) insufficient amount of budget funding for social institutions, which does not allow to improve the condition of the premises, purchase computer equipment, etc.;

5) impossibility for various reasons to master the funds of intergovernmental transfers, which leads to their inefficient spending and the need to return some unused transfers to the state budget.

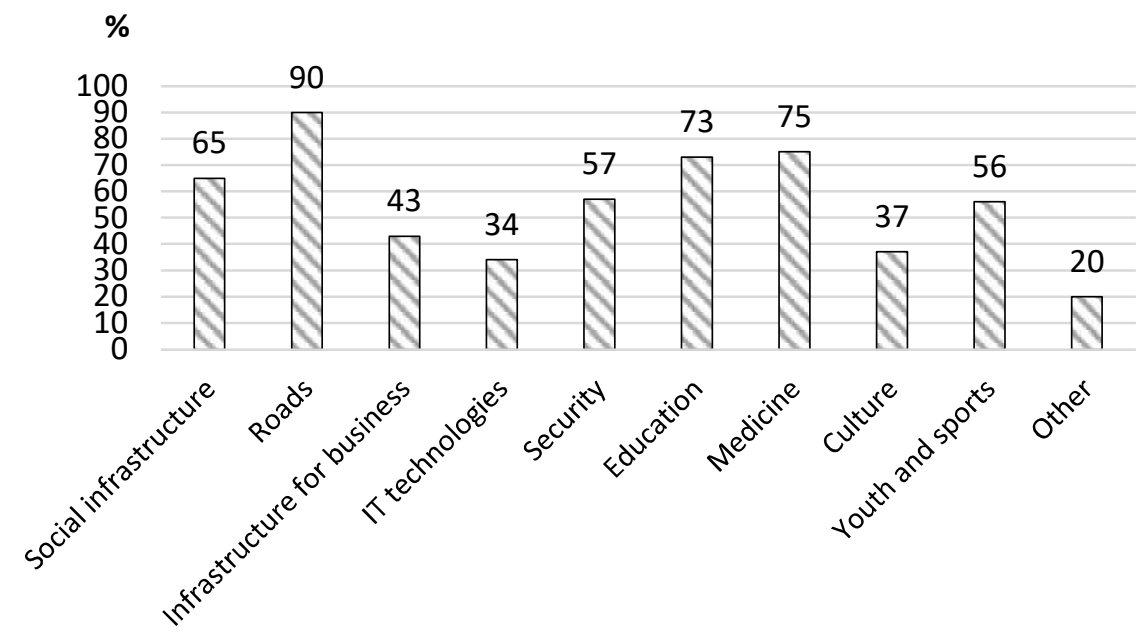

Fig. 3 - The most important areas for community development, identified by the results of the survey of UTC chairmen

Source: made by the authors on the basis of data [8] 
In the future, determining the alternative areas of financing the development of UTC, it is necessary to analyze the results of an express survey of UTC chairmen, which was conducted by the UTC Association by a survey through an online service. The purpose of this questionnaire was to find out what priorities the UTC chairmen set for themselves in terms of the main sources of funds for development and in terms of key areas in which funds should be invested in order to develop the community as soon as possible. At the same time, among the most important areas for community development, roads were identified as the first priority $(90 \%$ of respondents), medicine as the second one $(75 \%)$, and education as the third priority (73\%) (Fig. 3).
At the same time, today the majority of UTC chairmen (93\%) identify the infrastructure subvention as the most important source of funds for community development. However, after two or three years, the main source of funds, along with local budgets $(67 \%)$, more than half of the heads of UTCs $(55 \%)$ defined grants as international technical assistance (ITA) (Fig. 4).

In-depth analysis in terms of UTC types, it should be noted that ITA grants are currently one of the four most important sources of funds for community development. Thus, more than a third of urban, township and rural UTC identified them as the main source of funding for the development of their own area $-37 \%, 36 \%$ and $41 \%$ respectively (Fig. 5).

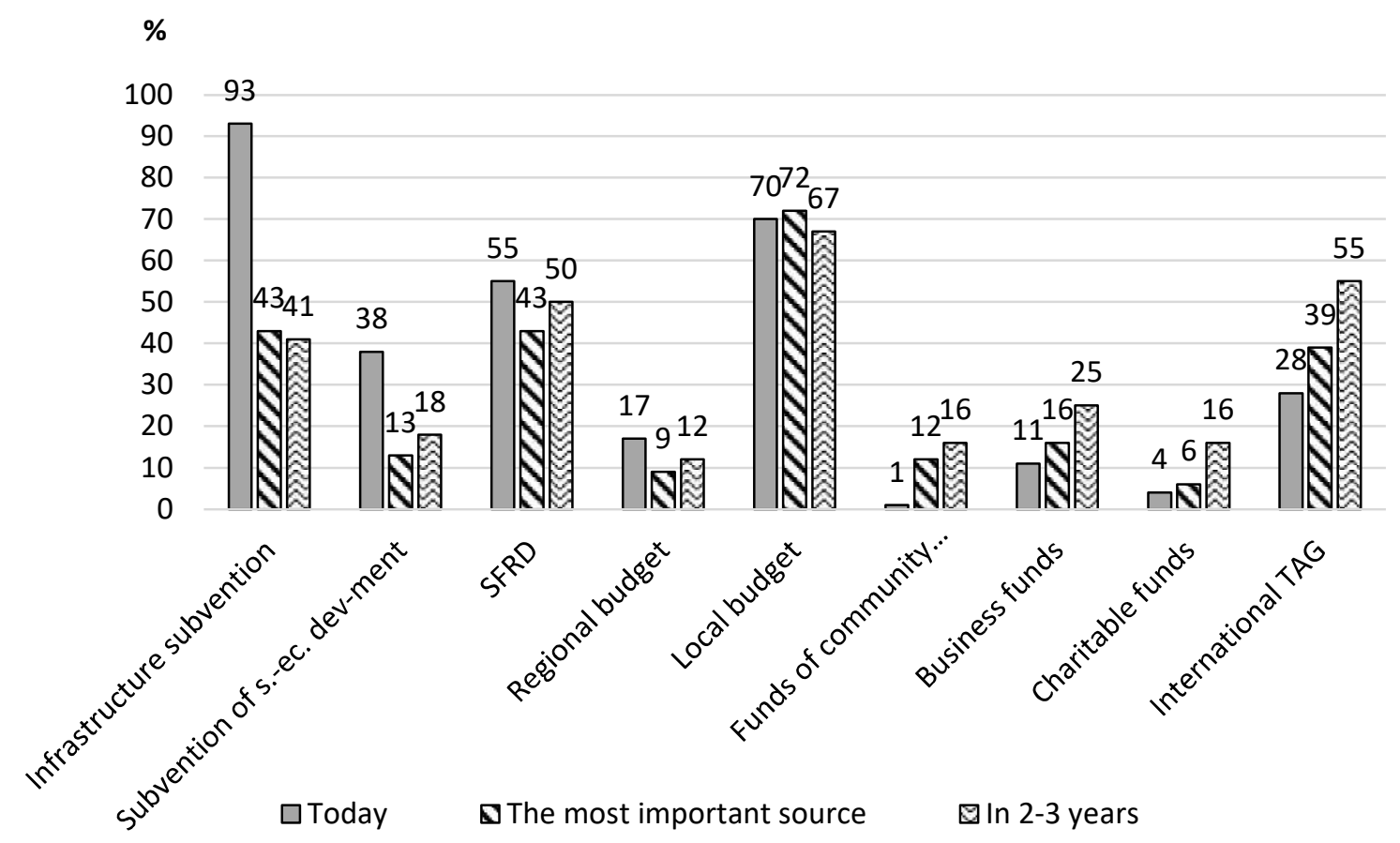

Fig. 4 - The main sources of funds for community development,

\section{identified by the survey of UTC chairmen}

Source: made by the authors on the basis of data [8]

It should be noted that today there is a number of promising funds like «Vidrodzhennia», «Dobre» (Decentralization Offering Better Resultsand Efficiency - DOBRE), «Support to Decentralization in Ukraine» (DESPRO), etc., which provide funds for the implementation of those projects that convince in their long-term existence and usefulness for the population and the economic infrastructure of
Ukraine in general. Such funds are formed mainly not only at the expense of domestic contributions, but also a significant share belongs to foreign development funds [9]. As a result, competition and incentives for self-financing appear between UTCs, social responsibility is formed and the consciousness of the population changes. 


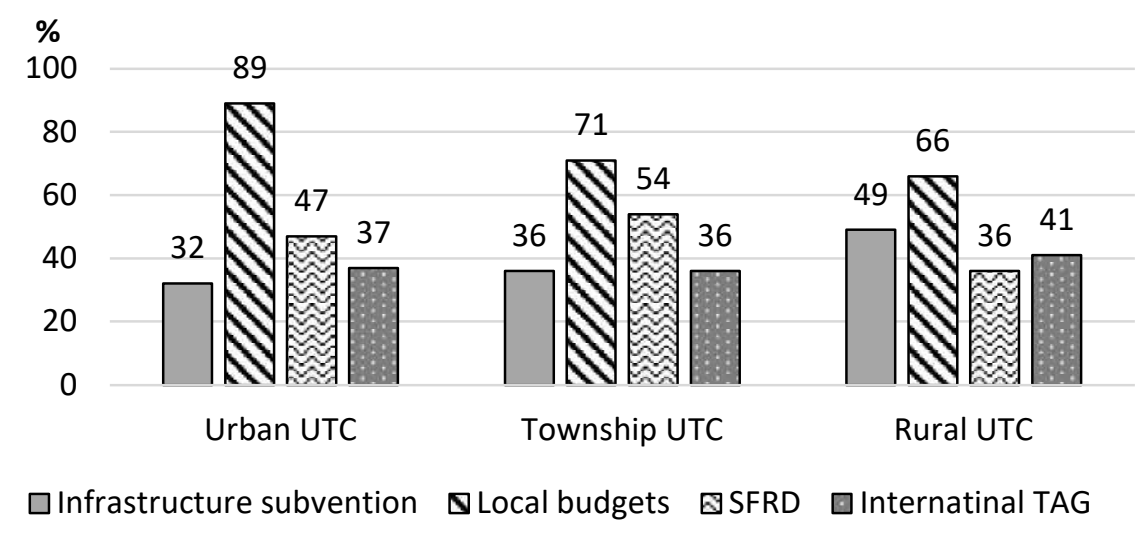

Fig. 5 - Four main sources of funds for community development, identified by the survey of UTC chairmen

Source: made by the authors on the basis of data [8]

Mykolayiv region is also an active participant in the formation of UTC and increasing their selffinancing opportunities for the economic prosperity of the region. As of the end of 2019, 30 UTCs have been established in the region. At the same time, the level of subsidization of their budgets (the share of the basic / reverse subsidy in revenues) ranges from $24.2 \%$ to $38.6 \%$. Thus, in Bashtanska UTC with a population of 22.6 thousand people, the level of subsidies is only 3.4 percent. This indicator is facilitated by the active position of the chairman and members of the UTC in the socio-economic development and development of projects financed from alternative sources.

Halytsynivska UTC is a successfully developed, financially viable community, which is one of the few that currently pays reverse to the state (the level of budget subsidies is 24.2 percent). Throughout the period of the community's existence, it is nonsubsidized, the reverse dotation in 2017 was UAH 12 million, in 2018 was UAH 16 million, in 2019 was UAH 23 million, in 2020 (plan) is UAH 26 million. Thanks to cooperation with public associations, the community cooperates with international donors, embassies and ministries of the EU and the USA: USAID DOBRE; Representation of DVV International in Ukraine; USAID Pact; Kyiv Dialogue Project; German Ministry of Foreign Affairs; Federal Ministry for Economic Cooperation and Development of Germany (BMZ). During this cooperation, 17 small and large projects were implemented.
Thus, such examples prove that increasing the level of self-financing capacity, attracting funds for promising projects, will contribute to further effective financial support for the development of UTC. This will create positive conditions for unloading the budget of Ukraine and provide an opportunity to direct these funds to other important social needs that are currently relevant for the country [9].

In order to increase the number of UTCs that will actively use alternative sources of funding, we have suggested an algorithm for attracting grant funds for the development of UTCs. It contains the defining features of attracting resources for grant programs (Fig. 6).

At the same time, it is important regularly to monitor the official websites of donor organizations and Internet resources that contain generalized information about grant competitions. In particular, the followings are quite informative and relevant: the resource center "Gurt"; the information portal of nonprofit organizations of Ukraine "Public space"; the crowdfunding platform "Big Idea"; the Ukrainian Association of township and rural Councils; the official portal "Decentralization"; the SwissUkrainian project "Support to Decentralization in Ukraine" (DESPRO); the International Foundation "Renesans"; Facebook group "Grants, competitions, scholarships" (https://www.facebook.com/groups/pr ogrants/); the directory of donors (http://foundations.org); the International Association of Public and Corporate Donors "European Foundation Center (EFC)"; the international portal for non-profit organizations and others. 


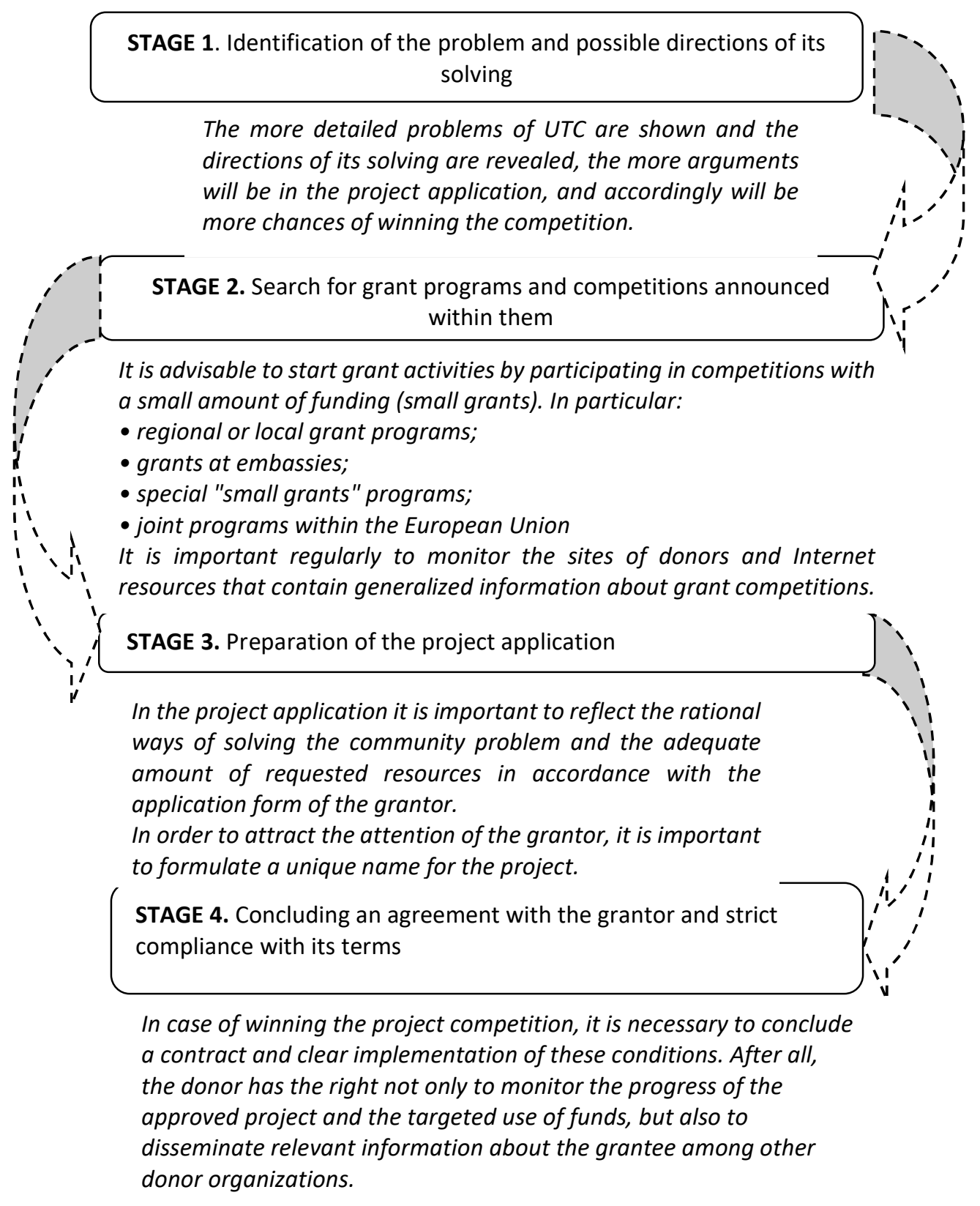

Fig. 6 - The algorithm for attracting grant funds for the development of UTC

Source: summarized and supplemented by the authors [10]

As the successful UTC experience shows, in order to increase the chances of receiving grant support, community members should participate in trainings, which are often conducted by donor organizations for potential participants in the future competition in the relevant area. In addition, it is important to ensure that the project application is in line with the strategic development plan of the community or region. After all, donor organizations usually prefer those socioeconomic development projects which prove viability at the stage after the completion of grant funding.

Conclusions. Conducted research has shown that the main task of budget decentralization is to find a sufficient amount of financial resources that will be able to provide full independence and autonomy of local budgets in the structure of the budget system of Ukraine. It is substantiated that along with the budget, investment and credit resources, the decisive role in financing local socio-economic development projects belongs to alternative sources in the form of grant funds. Implementation of the suggested promising projects through alternative sources of funding, consistent with the Community Development Strategy, will contribute to the formation of a favorable business environment and the implementation of social programs in UTC, increase financial capacity in the long run. Adherence to the algorithm suggested in the article and the development of skills to raise funds from alternative sources will be a determining factor in the success of local development of initiatives of the territorial communities of Ukraine. 


\section{References:}

1. Buryak, M. (2014), Administrative and financial decentralization as a factor in the development of subregional territorial communities. DSFA Bulletin. Economic sciences. 2014. № 1 URL : http://nbuv.gov.ua/UJRN/vddfae_2014_1_9.

2. Vasy'I'yeva, N., Gry'nchuk, N., Derun, T. \& Kujbida, V. (2017), Local budget and financial support of the united territorial community, Kyiv.

3. Poltorak, A. (2019), Financial security of the state in the conditions of globalization changes: theory, methodology, practice, Mykolayiv.

4. Spasiv, N. (2019), Estimation of structural imbalances of budget revenues of united territorial communities. The world of finance. Vol. 2.

5. On local self-government in Ukraine: the Law of Ukraine dated from May 21, 1997, № 280/97-BP URL: http://zakon2.rada.gov.ua/laws/show/157-19

6. Decentralization: Official website. URL: https://decentralization.gov.ua/

7. Public financial audit of united territorial communities: key problems and ways to solve them: analytical report (2019). Kyiv. URL: https://decentralization.gov.ua/uploads/library/file/520/12.2019_2.pdf

8. Association of United Territorial Communities: Official website. URL: https://hromady.org/

9. Lisova A., Mel’ny`k, O. (2019) Perspective directions of financial support for the development of united territorial communities. Efficient economy. Vol. 12. URL: http://www.economy.nayka.com.ua/pdf/12_2019/161_pdf

10. Vrublevs'ky`j, O. How to attract grants for community development: tips for elders URL: https://decentralization.gov.ua/news/10564

\section{А. С. Полторак, О. И. Мельник, И. В. Барышевская, Ж. В. Игнатенко. Альтернативные источники финансирования развития объединенных территориальных общин}

В статье доказано, что в современных условиях проведения децентрализации и дальнейшего развития объединенных территориальных общин (ОТО) важным является усиление их финансовой состоятельности через разные финансовые и социально-экономические механизмы. Проанализированы современные тенденции финансирования развития объединенных территориальных общин, раскрыты преимущества и возможности привлечения альтернативных источников финансирования. Предложен алгоритм привлечения грантовых средств для развития ОТО и другие предложения, способствующие повышению финансовой состоятельности ОТО на долгосрочную перспективу и реализации инициатив местного развития.

Ключевые слова: альтернативные источники финансирования, объединенные территориальные общины, гранты, проекты, финансовая состоятельность.

\section{А. С. Полторак, О. І. Мельник, I. В. Баришевська, Ж. В. Ігнатенко. Альтернативні джерела фінансування розвитку об'єднаних територіальних громад}

У статті доведено, що у сучасних умовах проведення децентралізації і подальшого розвитку об'єднаних територіальних громад важливим є посилення їх фінансової спроможності через різні фінансові та соціально-економічні механізми. Проаналізовано сучасні тенденції фінансування розвитку об'єднаних територіальних громад, розкрито переваги $і$ можливості залучення альтернативних джерел фінансування. Запропоновано алгоритм залучення грантових коштів для розвитку ОТГ та інші пропозиції, що сприятимуть підвищенню фінансової спроможності ОТГ на довгострокову перспективу та реалізації ініціатив місцевого розвитку.

Ключові слова: альтернативні джерела фінансування, об'єднані територіальні громади, грантові кошти, проєкти, фінансова спроможність. 